\title{
THE USE OF MECHANICAL CONTROL OF RESPIRATION IN ANAESTHESIA FOR THE OPEN CHEST
}

\author{
W. N. ROLLASON, M.B. (Birm.), M.R C.S. F F.A.R.C.S., D.A. (Eng.)
}

THE PRESENT EMPLOYMENT of automatic devices for rhythmic inflation of the lungs and the use of controlled respiration and curare to solve the problems of surgical pneumothorax ment tribute to the pioneer work of Green and Janeway nearly half a century ago, and to the far-sighted suggestions of Brat and Schmieden (1).

When controlled respiration is performed by a machine the information derived by the anaesthetist from the feel of the bag during inflation is lost This includes the depth of anaesthesia, the completeness of curarization, the presence or otherwise of conditions like bronchospasm, respiratory obstruction, and accumulation of secretions; the volume exchange that occurs when the bag is squeezed with a particular manual effort; the detection of every flicker of the diaphragm and every embryo cough; the observation of the volume changes due to the heart beat transmitted to the bag between inflations and the lessened resistance to ventilation from the relief of pulmonary congestion following successful mitral valvotomy or from excision of a portion of calcified pericardium or decortication of a lung.

Furthermore, unless the machine is "patient triggered," curanzation should be complete, although in this state the patient's energy can be conserved and oxygen consumption lowered by 10 per cent. Cardiac output may be reduced, especially at the peak of each inspiration, but this can be offset if the duration of inspiration does not exceed $1.5 \mathrm{sec}$, the inspiratory peak pressure does not exceed $25 \mathrm{~cm}$. of water and is rapidly reduced to atmosphenc, and the respiratory rate does not exceed 16-20 per munute. In this way neither circulation nor ventilation need be imperilled, provided the machine is capable of delivering 40-60 litres of aur per minute, and this is important to the severely ill patient.

Again, hyperventilation might result and lower the $\mathrm{CO}_{2}$ content thus raising the $\mathrm{pH}$ of the blood. Experimental observations, however, show this to be extremely unlikely with an open chest (3), and apnoea is probably largely due to inhibition of the Hering Breuer reflex as a result of rhythmic distension of the lungs.

There may be difficulty in assessing the depth of anaesthesia when the patient is apnoeic, but this matters little when nitrous oxıde with adequate oxygen is the anaesthetic, and with these agents diathermy can be used inside the chest.

Lastly, there may be a danger of further impacting plugs of sputum into the bronchi.

Nevertheless, mechanical control does set free the hands of the anaesthetist working alone and enables him to perform other tasks. These include the setting

"From a Panel Discussion on "Anaesthesia and the Open Chest," held, under the direction of Dr. S M Campbell, at the Annual Meeting of the Canadian Anaesthetısts' Society in the Banting Instutute of the University of Toronto, June 20,21, and 22, 1955.

- Consultant Anaesthetist to Hull A \& B Groups, Hull, England. 
up of transfusions and maintenance of a constant blood volume during the operation. This is particularly important in pneumonectorny where fluid replacement must be adequate and overloading avoided.

Repeated blood pressure and pulse readings are essential tó the proper management of any intrathoracic operation and particularly so when hypotensive and hypothermic techniques are employed. In the latter a constant watch must also be kept on the rectal or oesophageal temperature and on the electrocardiog am.

Furthermore, mechanical control reheves the physical fatigue of the araesthetust's hands and arms during long cases. Manual control tends to fall short of efficiency particularly if alternating positive and negative pressures are attempted, as, for instance, with a Coxeter Mushin machine.

Again, by maintaining a regular respiratory rhythm and constant pressure mechanical control enables the "dufferential pressure" respiration technique described by Esplen to be carried out more effectively than by hand (4). In this technique the lung which has remained collapsed can be re-inflated without dufficulty at the end of the operation even though this lasts several hours. No postoperative complications and no respiratory acidosis have ensued. The dif. ferental effect, however, cannot be properly demonstrated when multiple cavities or emphysematous changes are present in the lung on the operated side nor when an A.P or extensive lung disease is present on the contralateral side.

Lastly, some automatic respirators provide a negative pressure phase. This gives an adequate tidal volume with a smaller positive pressure during inspiration and is of value in reducing the right to left shunt when respiration is controlled in Fallot's Tetralogy and in arding the circulation by ensurin $y$ an adequate venous return in those cases where it is impaired, such as conditions of shock, hypovolaemia, and cardıac decompensation. A slight head-down tilt can further assist this venous return With negative pressures of -4 to $-6 \mathrm{~cm}$. of water mediastinal movement is very slight for all respiratory activity is abolished by completely satisfyng the respiratory requirements of the patient The machines described by Pinson (5), Mørch (6), Esplen (7), and Mortimer (8) all provide a negative phase; the Jefferson ventilator which is used on this continent is capable of providing regative pressures up to $10 \mathrm{~cm}$. of water; and the new Blease machine which is now being manufactured in England provides negative pressures up to $7 \mathrm{~cm}$. of water (9).

As a result of an experimental study of pulmonary histopathology in dogs with open chests following positive and negative pressure respiration, he conclusion was drawn that the most favourable endotracheal pressure allowing effective pulmonary ventilation with minimal lung damage was $15-20 \mathrm{~cm}$. of water positive pressu $e$ and $5 \mathrm{~cm}$. of water negative pressure (10).

Blood pressure in the superior vena cava in dogs has been directly measured by the use of an electrically recording stream bristle flowmeter; in the open chest, while positive oressure lung inflation impeded venous return, the interposition of a negative prase between positive pressure lung inflations did not benefit the circulation significantly (11).

On the other hand, in a human subject undergoing pneumonectomy the cardiac output calculated from the indirect Fick principle fell to 2.68 litres per minute 
during anaesthesia with assistance by a prolonged phase and rose to 5.34 litres per minute during anaesthesia where there was assistance with both inflation and deflation (12).

No deleterious effects have been noted during or following operations where a negative phase of up to $5 \mathrm{~cm}$. of water has been employed

In addition, however, to providing a negative phase the modern mechanical automatic respirator should guarantee the following

1. It should measure and be able to reproduce a certain tidal volume, which should not fall below $350 \mathrm{cc}$. in the adult (13).

2. It should be sensitive to pressure changes within the chest so that "cycling" (i e., change from expiratory to inspiratory phase and vice versa) occurs at a peak pressure.

3. The inspiratory pressure shouid be variable from atmospherıc to a maximum of $30 \mathrm{~cm}$. of water, the higher pressure being required for inflation of the lungs on closure.

4. Inspiratory and expiratory phases must be variable so as to simulate the normal respiratory pattern of a fairly rapıd intial flow, tailıng off as the alveoli fill and exchange takes place, with a quick return to atmospheric or subatmospheric pressure on expiration, the wide range of control makes the respirator suitable for use with children as well as adults.

5. It should be possible to hold the lungs inflated at will and at varying pressures.

6. It should be possible to switch over to spontaneous respiration if desired.

7. There should be a mechanism for switching over to a rebreathing bag for manual control in cases of failure of the mechanism of the machine.

8. There should be a spll valve to enable the machine to be used with nitrous oxide and oxygen anaesthesia and an efficient humidifer incorporated when these gases are used.

9. There should be a means of holding a small positive pressure up to $5 \mathrm{~cm}$ of water at the end of expiration

10. The machine should be adaptable to any technique of anaesthesia and should be explosion proof.

The new Blease machine is probably the most highly developed piece of equipment of its type at present available and meets all these requrements.

In conclusion, however, I would stress that the automatic respirator, valuable though it can be, is only an ancllary and It is no substitute for keen clinical observation or constant viglance, and as there is valuable information and delicate control which can only be imparted by the sensitive and skilled human hand, a technique combining manual and mechanical methods is the most useful in practice.

\section{RÉsUMÉ}

Lorsqu'il contrôle la respiration mécaniquement, l'anesthésiste est incapable de connaître le profondeur de l'anesthésie, le degré de relâchement musculaire et aussi, la présence d'obstruction respiratoire due soit a un bronchospasme soit aux sécrétions, ou encore, les variations de résıstance dépendant de la congestion pulmonaire. 
Il y a aussi le danger d'interférence avec le remplissage et l'évacuation cardiaques par suite de la régulation inadéquate des pressions, de l'air courant et de la longueur du cycle respiratoire.

Le contrôle mécanique libère l'anesthésiste et lui permit d'utiliser ses mains pour d'autres tâches. De plus, s'il est bien régularisé, il produit une ventilation plus efficace. Avec l'addition d'une phase négative allant jusqu'à $5 \mathrm{~cm}$. d'eau dans les appareils les plus modernes, le débit cardiac est augmenté.

Le respirateur automatıque moderne doit être capable de mésurer et de produre un volume requis d'air circulant de pas moins de $350 \mathrm{cc}$. chez l'adulte. Il doit pouvoir produre une pression positive allant jusqu'à $30 \mathrm{~cm}$. d'eau lors de l'inflation du poumon quand on ferme un thorax. Les phases inspiratoires et expiratoires doivent être de contrôle facile de façon à être adaptab e aux enfants aussi bien qu'aux adıltes. Il devraut être possible de passer sans dificulté soit au contrôle manuel soit à la respiration spontanée. Il faut qu'il puisse servir pour tous les types d'anesthésie $\mathrm{Il}$ ne devrait pas y avoir danger d'explosion.

Un respirateur mécanıque doit être considéré seulement comme un adjuvant et non un substitut de l'observation clinique et de la vigilance constante.

\section{REFERENCES}

1 Mushin, W W \& Rentell-Baker, L Principles of Thoracic Anaesthesia. Oxford Blackwell (1953).

2 Spalding, J M K. Lancet, May 281099 (1955)

3 Lucas, B G B \& Milne, E. H Proc Roy. Soc. Med 46368 (May 1953)

4 Esples, J R Brit. J. Anaesthesia 23: 214 (October 1951)

5 Pinson, K B Anaesthesia 479 (April 1949)

6 Мфлсн, E Trier Anaestbesia 34 (January 1948)

7 Esplen, J R, "The Fazakerley Respiratory", Personal communication

8 Mortimen, P L F Anaesthesia $\theta 312$ (October 1954)

9 Blease, J H Personal cornmunication

10 Waltz, R C et al Surg, Gynec \& Obst 99 (November 1954)

11 Hubay, C A et al Anesthesiology 15445 (September 1954)

12 Allphitten, F F, Jr, et al Ann Surg 140576 (October 1954)

13 Harbond, R P et al Proc Roy Soc Med.46 367 (May 1953) 